University of California, Hastings College of the Law UC Hastings Scholarship Repository

Faculty Scholarship

1998

\title{
Trust Law in the United States. A Basic Study of Its Special Contribution
}

Ugo Mattei

UC Hastings College of the Law, matteiu@uchastings.edu

Henry Hansmann

Follow this and additional works at: http://repository.uchastings.edu/faculty_scholarship

\section{Recommended Citation}

Ugo Mattei and Henry Hansmann, Trust Law in the United States. A Basic Study of Its Special Contribution, 46 Am. J. Comp. L. Supp. 133 (1998).

Available at: http://repository.uchastings.edu/faculty_scholarship/1290

This Article is brought to you for free and open access by UC Hastings Scholarship Repository. It has been accepted for inclusion in Faculty Scholarship by an authorized administrator of UC Hastings Scholarship Repository. For more information, please contact marcusc@uchastings.edu. 
TOPIC II.A.3

\section{HENRY HANSMANN \& UGO MATTEI}

\section{Trust Law in the United States. A Basic Study of Its Special Contribution}

In the United States, academic commentary and law school curricula continue to focus on the private trust in its historical role as a device for intrafamily wealth transfers, a rather technical and narrow ground to approach our topic. Vastly more important is today the enormous - though commonly neglected - role that private trusts have come to play in the American capital markets. ${ }^{1}$ To take just the most conspicuous examples, pension funds and mutual funds, both of which are generally organized as trusts, together now hold roughly forty per cent of all U.S. equity securities and thirty per cent of corporate and foreign bonds. ${ }^{2}$ Similarly, turning from the demand side to the supply side of the securities markets, asset securitization trusts are now the issuers of a large fraction of all outstanding American debt securities - more than $\$ 2$ trillion worth. ${ }^{3}$

This report rather then following the details of trust law as described in American law books will focus on the general economic functions served by a separate law of trusts. We shall explore what the law of trusts adds to the law of contract and agency. That is, what useful relationships can be established with the law of trusts that cannot be established with roughly similar ease using just the more basic tools of contract and agency law? In very general terms,

Henry Hansmann is Professor of Law, Yale Law School.

Ugo MatTer is Alfred and Hanna Fromm Professor of International and Comparative Law, Hastings College of Law, University of California.

This Report is an American based abridgment of a broader comparative study; the complete essay is Hansmann \& Mattei, "The Functions of Trust Law: A Comparative Legal and Economic Analysis," NYU L. Rev. 434 (1998). A version, more focused on the civil law alternatives to trust is published as Ch. 7 of Ugo Mattei, Comparative Law and Economics (1997).

1. A recent and important exception to the general neglect of the new commercial trusts is Langbein, "The Secret Life of the Trust: The Trust as an Instrument of Commerce," 107 Yale L.J. 165-89 (1997).

2. U.S. Department of Commerce, Bureau of the Census Statistical Abstract of the United States 1996 523, Table No. 806 (1996). Only 14 years earlier, in 1980, private pension funds and mutual funds held only $20 \%$ of equities (though $35 \%$ of bonds), id., and the percentage of mutual funds organized as trusts was also much lower.

3. Ingo Walter \& Roy Smith, Global Banking 201, Figure 7-6 (1997). 
our answer is that the most important contribution of the law of trusts is that it facilitates the partitioning of assets into bundles that can conveniently be pledged separately to different classes of creditors. Of particular importance in this respect is the use of trust law to shield trust assets from claims of the trustee's personal creditors. In contrast, the function of trust law that is the primary subject of the literature in the common law countries, namely the creation and enforcement of fiduciary duties, seems a relatively unimportant reason for maintaining a separate law of trusts.

\section{Trust AND Equity}

In a prototypical Anglo-American trust, three parties are involved: the "settlor" transfers property to the "trustee," who is charged with the duty to administer the property for the benefit of the "beneficiary." Any of these three roles may be played by more than one person. Also, the same person can play more than one of the three roles. In particular, the settlor and the beneficiary can be the same person, in which case the trust involves a simple delegation of responsibility for managing property from the settlor/beneficiary to the trustee.

The Anglo-American concept of the trust, together with the equity jurisprudence of which it forms a part, are the fortuitous product of the peculiar historical path followed by English law.

Prior to the intervention of equity, an effort to create an enforceable trust-like relationship under the common law would fail. The Trustee would become the full owner of the property in trust and her obligation to administer that property for the advantage of the Beneficiary would be purely moral: because she was the full owner, neither the Settlor nor the Beneficiary could claim anything against the Trustee in a common law court. Ultimately equity, in contrast, recognized that, while the Trustee was the owner at law, her right was restricted by another property interest, that of the Beneficiary. ${ }^{4}$ Beneficiaries were therefore provided with equitable remedies against an unfaithful Trustee. This system of rights and remedies was described by saying that the Trustee had legal ownership while the Beneficiary had equitable ownership. ${ }^{5}$

This subdivision of property rights caused little conceptual difficulty in the common law system which, from an early stage, recognized that property rights need not be concentrated in the hands of a

4. A forerunner of equity in this respect was the canon law. Helmholz, "The Early Enforcement of Uses," 79 Col. L. Rev. 1503 (1979), shows that ecclesiastical courts were available to sanction directions given by testators to hold property according to the testator's will.

5. For an early example see J. H. Baker \& S. F. C. Milsom, Sources of English Legal History 103 (1986). 
single owner but rather could be divided among more than one individual, either in time (estates) or in content (incidents of tenure). Since the beneficiaries were considered property owners, and not holders of mere contractual rights, it naturally followed that they could claim their interests against everybody (except against a purchaser for value without notice) and had proprietary remedies. On the other hand, since the trustee held legal title to the trust property, his transfers of property were not impaired by the existence of the trust. ${ }^{6}$ Rather, when the trustee exchanged the trust property for other property, the beneficiary's interest and the trustee's duties attached to the new property received in the exchange. Moreover, if the trustee wrongfully transferred trust property to somebody other than a purchaser in good faith without notice of the trust, then, through the remedy called "tracing," the beneficiary's property interest continued to attach to the property, and the transferee was considered to hold the property and all of its proceeds in trust for the beneficiary, who was the equitable or beneficial owner of the property. ${ }^{7}$

\section{The Basic Economic Structure of Trust}

At its core, a modern trust involves contractual relationships ${ }^{8}$. The institution of the trust offers a set of standard terms for those relationships - in effect, default terms that will be implied in the absence of explicit language to the contrary in the parties' contract. The utility of the trust as a legal institution turns on the efficiency of having this set of standard terms, which in turn requires, in general, two things: (1) the standard terms must be efficient in themselves, which is roughly to say that they are the terms that the parties would agree to if they could bargain costlessly between themselves; (2) the transaction costs of negotiating at least some of those standard terms would be significantly higher if the parties could employ only the basic law of contract, property, and agency. In short, the trust is a useful legal form if it reduces in an important way the transaction costs of contracting. (To be sure, this formulation is a bit too simple; ${ }^{9}$ we shall refine it further below.)

To see whether and how the law of trusts meets this test, we shall examine, in turn, the principal transactional relationships affected by a trust.

6. For discussion, see Rudden \& Graziadei, "Il Diritto Inglese dei Beni ed il Trust: Dalle Res al Fund," Quadrimestre 458 (1992).

7. See supra n. 1 , at 295 .

8. See Langbein, "The Contractarian Basis of the Law of Trusts," 105 Yale L. J. 625 (1995).

9. On the economics of default rules generally, see Schwartz, "The Default Rule Paradigm and the Limits of Contract Law," 3 S. Cal. L. Rev. 389 (1993). 


\section{The Relationship Between Settlor and Trustee}

With respect to the contractual relationship between the Settlor and the Trustee, the role of the law of trusts in providing a standard set of default terms is conspicuous. So long as the parties characterize the relationship they wish to establish as a "trust," or even if they just make clear their intention to create a trust-like relationship, ${ }^{10}$ the law of trusts automatically inserts a variety of standard terms into their agreement. These terms comprise the core of the trust relationship. They include the powers of the Trustee, such as the authority to incur expenses in the administration of the property in trust and the power to lease, mortgage, or sell the property in trust where appropriate. ${ }^{11}$ They also include the duties of the Trustee toward the Settlor (and, by derivation, toward the latter's intended third party beneficiary, the Beneficiary), such as the duty to preserve the trust property and render it productive, and to pay income to the Beneficiary. ${ }^{12}$ Among those duties are the Trustee's fiduciary duties: the duty of care (duty to exercise reasonable care and skill) ${ }^{13}$ and the duty of loyalty (the duty not to deal with the property in trust contrary to the Settlor's and the Beneficiary's interests). ${ }^{14}$

These default terms are unquestionably a convenience. But that is all they are. If the law of trusts did not exist, the Settlor and the Trustee could still establish between themselves the obligations that are at the core of the private trust.

The law of trusts relieves the Settlor and the Trustee of the burden of explicitly spelling out all of the Trustee's powers and duties. Also, to the extent that the parties seek to deviate from the standard default rules (which the law of trusts generally permits), the law of trusts puts the burden on the parties to be explicit, and thus helps assure that both parties are aware of, and thoughtfully accept, those nonstandard terms. Yet essentially the same results could be achieved through contract in the absence of trust law simply through the use of privately-drafted standard form contracts. This is true, in particular, for the fiduciary duties of the Trustee, which can easily be established by contract - most obviously, just by inserting into the contract between the Settlor and the Trustee the same language concerning the Trustee's duties that presently appears in the sections of the Restatement of Trusts describing a trustee's duties.

Indeed, since the Trustee would generally be deemed by the law to be the Settlor's agent, in the absence of trust law the law of agency

10. See Restatement of Trusts (Second) $\S \S 23,24$ (concerning the forms in which the intention to create a trust can be manifested).

11. Id. $\S \$ 186-96$.

12. Id. $\$ \S 169-85$.

13. Id. $\$ 174$.

14. Id. $\$ 170$. 
would apply and would itself, if the parties' contract did not say otherwise, impose fiduciary duties on the Trustee that are quite close to those implied by the law of trusts. ${ }^{15}$ To be sure, the duty of loyalty that is the default rule in trust law is slightly more rigorous than that implied by the law of agency. ${ }^{16}$ This is appropriate. In trust-like relationships the principals involved (the Settlor and the Beneficiary) are commonly not well situated to monitor the Trustee in fulfilling her duties as their agent - for example, because the Settlor is dead and the Beneficiary is incompetent or a child. Nevertheless, in the absence of trust law, the Settlor and the Trustee would still be free to establish this stricter duty of loyalty by explicit contractual provisions that substitute it for the default rules of agency law.

\section{The Relationship Between Trustee and Beneficiary}

The standard rule in trust law is that the Beneficiary has the power to enforce the Trustee's performance of her duties. ${ }^{17}$ The obvious rationale for this rule is that otherwise there might be nobody with both the incentive and the capacity to police the Trustee.

The traditional English rule of common law is that third party beneficiaries of a contract have no authority to enforce the contract. ${ }^{18}$ As a consequence, in England the law of trusts historically served, and still serves, the important function of permitting the creation of trust-like relationships with effective powers of enforcement - something that could not be done in the absence of trust law. In other common law jurisdictions, however, this is not the case. In the United States, for example, after 1859 the old common law restrictions on third party enforcement were gradually abandoned, with the result that today an intended third party beneficiary of a contract will be permitted to enforce that contract. 19 Consequently, trust law in the United States is no longer necessary to achieve that result. A more vital function of trust law lies in arranging the expectations of the personal creditors of the Settlor, Trustee, and Beneficiary.

15. Compare Restatement (Second) of Agency $\$ \S 387-90$ with Restatement (Second) of Trusts $\$ 170$ (duty of loyalty); Restatement (Second) of Agency $\$ 386$ with Restatement (Second) of Trusts $\$ 174$ (duty of care and skill).

16. A trustee dealing with trust property on his own behalf is held to a standard of fairness even if he obtains the informed consent of the beneficiary, while such a standard of fairness is not imposed on similar transactions between an agent and his principal. Compare Restatement (Second) of Agency \$390, comment c, with Restatement (Second) of Trusts $\$ 170$, comment w.

17. Restatement (Second) of Trusts $§ \$ 197-99$.

18. See Vernon Palmer, The Paths to Privity: The History of Third Party Beneficiary Contracts in English Law (1992); Andrews, "Does a Third Party Beneficiary Have a Right in English Law?," 1988 Legal Studies 14.

19. See Waters, "The Property in the Promise: A Study of the Third Party Beneficiary Rule," 98 Harv. L. Rev. 1111 (1985). 


\section{The Beneficiary's Creditors}

One important way in which the Beneficiary can derive benefits from the property in trust is to offer his interest in it as security for credit, whether the Beneficiary does this explicitly by pledging his interest in the property in trust to creditors or implicitly by inducing persons to extend unsecured credit to him in reliance on the Beneficiary's overall wealth, which includes his interest in the property in trust. Consequently, one would expect that the Settlor would generally wish to permit the Beneficiary's creditors to be able to levy on the Beneficiary's interest in the property in trust in case of the Beneficiary's insolvency, and that the Settlor would therefore wish to provide for this result through his contract with the Trustee. Thus, it is reasonable for the law of trusts to make this result one of the standard terms that will be imputed to the parties absent explicit provision to the contrary - as, in fact, it does. ${ }^{20}$

On the other hand, if the Settlor is concerned that the Beneficiary is irresponsible and will too quickly encumber all of the property in trust, the Settlor might wish to avoid the standard result and, instead, make the Beneficiary's interest in the property in trust unavailable to the Beneficiary's creditors. American trust law in fact permits the settlor to do this by creating a "spendthrift trust" that bars the beneficiary's creditors from levying on the beneficiary's interest in the trust. ${ }^{21}$ This is a reasonable arrangement, except that it runs the risk of misleading persons who extend credit to the Beneficiary on the basis of his apparent wealth, only to discover subsequently that this wealth is beyond their reach. The efficiency of the spendthrift trust is consequently debatable; the paternalistic protection it provides for hapless beneficiaries may not outweigh the costs it engenders by confusing creditors' expectations. Not surprisingly, therefore, the wisdom of recognizing spendthrift trusts has been a perennial subject of controversy in American legal commentary, ${ }^{22}$

20. Restatement (Second) of Trusts $\$ 147$.

21. See Restatement (Second) of Trusts \$\$150-55.

22. Famous and forceful criticism of the spendthrift trust was voiced long ago by Harvard Law School Professor John Chipman Gray in his book Restraints on the Alienation of Property (1883), written in response to the Supreme Court's validation of spendthrift trusts in Nichols v. Eaton, 91 U.S. 716 (1875). "The general introduction of spendthrift trusts would be to form a privileged class, who could indulge in every speculation, could practice every fraud, and, provided they kept on the safe side of criminal law, could yet roll in wealth." Id. at 262.) A recent installment in the debate is Hirsch, "Spendthrift Trusts and Public Policy: Economic and Cognitive Perspectives," 73 Wash. U. L.Q. 1 (1995), which surveys the issues at length and argues (somewhat casually) that, whatever may have been the case in the past, spendthrift trusts today do not create serious problems for creditors in assessing a debtor's creditworthiness - or that, if they do, the resulting distortions in credit terms tend to be offset by other information problems that creditors face. 


\section{and English law has refused to recognize spendthrift} trusts. ${ }^{23}$

In the United States, a third party beneficiary's enforceable interest in a contract can be assumed by a trustee in bankruptcy for the benefit of the beneficiary's creditors. ${ }^{24}$ Thus, the default rule established under the law of trusts is replicated by contract law, and the law of trusts adds little. The spendthrift trust, on the other hand, appears difficult to replicate through the general tools of contract law $^{25}$ - for the same reasons, presumably, that it is a controversial device in the law of trusts.

\section{The Settlor's Creditors}

Under trust law, the settlor's creditors generally cannot reach the trust property so long as the settlor is not also a beneficiary of the trust. ${ }^{26}$ This is a logical result; it follows what we can generally presume to be the intent of the contracting parties (and particularly the

23. The case that remains controlling to this day is Brandon v. Robinson, 34 Eng. Rep. 379 (Ch. 1811). England has, however, developed alternatives to the spendthrift trust, principally in the form of "discretionary trusts" and "protective trusts" that give the trustee substantial discretion concerning distributions to the beneficiary, and thus leave the beneficiary with an interest that is considered too uncertain to be reachable by the beneficiary's creditors. See E. N. Griswold, Spendthrift Trusts 367, 429 (1936); George Bogert, The Law of Trusts and Trustees 221 (1987).

24. The Bankruptcy Code, 11 U.S.C. $\$ 541(a)(1)$, defines the bankrupt estate as consisting of "all legal or equitable interests of the debtor in property as of the commencement of the case." Among the debtor's legal interests that become a part of the bankruptcy estate under the Code are his choses in action and claims against third parties. These choses in action and claims clearly include rights of action based upon contract. See, e.g., Guarles House Apartments v. Plunkett (In re Plunkett), 23 B.R. 392 (Bankr. E.D. Wis. 1982); Varisco v. Oroweat (In re Varisco), 16 B.R. 634 (Bankr. M.D. Fla. 1981); Rau v. Ryerson (In re Ryerson), 739 F.2d 1423 (9th Cir. 1984); Buckeye Union Insurance Co. V. Four Star Construction Co. (In re Four Star Construction Co.), 151 B.R. 817 (Bankr. N.D. OH 1993). Whether a third party beneficiary has an enforceable contractual right - and hence one that clearly becomes part of the bankruptcy estate - turns on his classification as an "intended" or "incidental" beneficiary. And the definition of "intended beneficiary" in this regard is broad enough to cover virtually anyone who is the Recipient in a trust-like relationship. Restatement (Second) of Contracts $\$ \S 302,304,315$. For cases involving a bankruptcy trustee's assumption of a debtor's rights as a contractual third party beneficiary, see, e.g., Newton v. Johnston (In re Johnson and Associates, Inc.), 845 F.2d 1395 (6th Cir. 1987); Nat'l Tax Credit Partners v. Havlik, 20 F.3d 705 (7th Cir. 1994); Whinnery v. Bank of Onalaska (In re Taggatz), 106 B.R. 983 (Bankr. W.D. Wis. 1989); Farmer v. Crocker Nat'l Bank (In re Swift Aire Lines, Inc.), 20 B.R. 286 (Bankr. C.D. Cal. 1982).

25. To avoid the consequences described in supra, the Settlor and the Trustee might provide explicitly in their contract that, while the Beneficiary is intended to benefit from the Trustee's performance, the Beneficiary is to have no powers to enforce the contract. But, even if unenforceability would be sufficient to ensure exclusion of the Beneficiary's interest from his estate in bankruptcy, that exclusion would come at the price of eliminating the legal accountability of the Trustee to the Beneficiary.

26. This is the negative implication of Restatement (Second) of Trusts $\$ 156$ (creditors can reach settlor's interest in a trust where settlor is also a beneficiary of the trust). See also 11 U.S.C. $\$ 541(\mathrm{~b})(1)$, discussed infra n. 34 . 
settlor), and in general it should not mislead the settlor's creditors (who have no reason to rely on the value of the trust property in extending credit to the settlor, since title to the property is in the hands of the trustee and no material benefits are flowing to the settlor from the property).

On the other hand, trust law provides that if the settlor himself retains a beneficial interest in the trust property, then his creditors can reach his interest in that property even in the face of explicit efforts on his part to provide, in the terms of the trust, that his creditors may not reach his interest. ${ }^{27}$ This result, too, is logical, to prevent the settlor from intentionally or unintentionally misleading his creditors as to his ability to repay them.

As with the rights of the Beneficiary's creditors, however, these are apparently the results that would obtain even if the parties did not have the advantage of the law of trusts, and had to rely only upon general principles of contract law. ${ }^{28}$

\section{The Trustee's Creditors}

Under the common law of trusts, if the trustee becomes insolvent, the trust property she administers is unavailable to satisfy the trustee's obligations to her personal creditors. ${ }^{29}$

This arrangement has important advantages. To begin with, it is what all three of the principal parties would generally prefer. The Settlor presumably wishes to transfer the value of the trust property to the Beneficiary, free of possibilities that the transfer will be frustrated through forfeiture of the property to the Trustee's creditors. To be sure, the ability to use the trust property as security for credit is one means by which the Settlor might compensate the Trustee for the latter's efforts. But direct cash payments should nearly always be a superior form of compensation.

Furthermore, in typical situations in which trusts are employed, often neither the Settlor nor the Beneficiary is well situated to monitor the other business affairs of the Trustee, and in particular to check regularly on the Trustee's solvency. Thus, they are in a poor

27. Id.

28. Absent the law of trusts, if a Settlor transfers to the Trustee the title to the property, in trust and enters into a contract with the Trustee under which the latter is to manage the property exclusively for the benefit of a third party Beneficiary, then the only interest that the Settlor retains is a contractual right to enforce the Trustee's duties toward the Beneficiary; he has no contractual claim on the interest or principal of the property in trust to be levied on. See 11 U.S.C. $\$ 541(b)(1)$, which excludes from the bankruptcy estate any power that the debtor may only exercise solely for the benefit of a person other than the debtor.

29. Bankruptcy Code, 11 U.S.C. $\$ \$ 541(\mathrm{a})(1), 541(\mathrm{~d})$; Restatement (Second) of Trusts §§306-08, 221; Todd v. Pettit, 108 F.2d 139 (5th Cir. 1939); American Serv. Co. V. Henderson, 120 F.2d 525 (4th Cir. 1941); In re Tate Jones \& Co., 85 F. Supp. 971 (W.D. Pa. 1949). 
position to control the extent to which the Trustee exposes the property in trust to claims of the Trustee's creditors. (Consider, again, the classic situation in which the Settlor is dead and the Beneficiary is incompetent or a child.) In contrast, with the rules of trust law in effect, simple accounting measures can easily signal, to potential creditors of the Trustee, which of the property in the Trustee's possession is held in trust and hence is not available to satisfy the creditors in case of the Trustee's insolvency, so that the creditors can adjust their terms of credit to reflect the amount of security available to them. Indeed, by establishing the trust as a standard form, the law of trusts makes such signalling easy: the Trustee need simply use the words "in trust" when registering the property or otherwise dealing in it.

Of course, where the Trustee is not careful in such signalling, there arises the possibility of inducing inappropriate reliance on the property in trust by the Trustee's creditors. In such cases the law of trusts nevertheless favors the beneficiary. Indeed, even if the trustee intentionally breaches her duty to the beneficiary, and specifically pledges trust property as security for credit extended to the trustee by a third party creditor who is unaware that the property is held in trust, the creditor will not be permitted to enforce his security interest in the trust property, which instead will remain available only to the beneficiary. ${ }^{30}$ Even here, the law apparently presumes that the Trustee's creditors are in a better position than the Beneficiary to look out for themselves (or, to use the conventional Calabresian terminology, that they are the cheapest cost avoiders).

In sum, where claims of the Trustee's personal creditors are involved, the default rule implied by the common law of trusts appears to economize on total information and monitoring costs for all the contracting parties involved - the Trustee, the Settlor, the Beneficiary, and the Trustee's personal creditors.

In the absence of trust law, the result would presumably be the reverse: since the Trustee holds title to the property in trust, the Property in trust would be presumed subject to levy by the Trustee's creditors. ${ }^{31}$

30. Restatement (Second) of Trusts \$286. The law is different in the case of third party purchasers of the legal title to trust property who act in good faith and pay reasonable value: they get good title to the trust property even if the trustee sells in breach of trust. Id. \$284. It is only those third parties to whom the breaching trustee transfers mere equitable title who are disfavored vis-a-vis the beneficiary.

31. The question "what would be the rights of the Trustee's creditors in the United States, with respect to the property in trust, absent the law of trusts?" is not entirely well defined in American law. The relevant provision in the bankruptcy law does not explicitly refer to trusts. Rather, it states:

Property in which the debtor holds, as of the comencement of the case, only legal title and not an equitable interest, such as a mortgage secured by real property, or an interest in such a mortgage, sold by the debtor but as to which the debtor retains legal title to service or supervise the servicing of 
In principle, even without the law of trusts the same insolvency rule concerning the Trustee's personal creditors could be established by contractual means. The Trustee could insert, in each contract she enters into with one of her personal creditors, a term providing that the creditor foreswears any claim against the property in trust in case of the Trustee's breach. Moreover, the Trustee could promise, in her contract with the Settlor, to put such a term in every personal contract that the Trustee enters into. Yet the transaction costs of this approach would often be prohibitively high. Consider, as one obvious example, the difficulties that would arise when the Trustee deals with other parties that themselves use standard contractual forms. There would also remain the risk that, even where it is otherwise practicable, the Trustee would sometimes omit to insert the required contractual term out of carelessness or opportunism, and the Trustee's performance in this regard would be very difficult for either the Settlor or the Beneficiary to police.

The rule governing claims to the property in trust in case of the Trustee's insolvency is therefore, unlike the other trust doctrines we have discussed so far, an important contribution of the law of trusts, permitting parties to enter into useful contractual relationships that can be replicated only at substantial cost, if at all, using just the basic tools of contract and agency law.

\section{Liability of the Trustee}

Under trust law, the trustee is presumed personally liable to third persons on all contractual and other obligations she incurs in the course of administering the trust. ${ }^{32}$ The trustee can avoid such personal liability on contracts, however, if she makes it clear when

such mortgage or interest, becomes property of the estate . . only to the extent of the debtor's legal title to such property, but not to the extent of any equitable interest in such property that the debtor does not hold.

Bankruptcy Act of 1978, 11 U.S.C. \$541(d). It is well established that this rule immunizes trust property from claims of the trustee's personal creditors in bankruptcy; see the cases cited supra $n$. 56. If American law were to be deprived, not just of the law of trusts, but of the law of equity in general, presumably the provision just quoted would have no reference, and any property to which the bankrupt holds legal title would become part of the bankruptcy estate.

But what if one were to eliminate just the law of trusts in the United States, while retaining the law of equity? Absent trust law, as we have suggested, the natural alternative would be to transfer title to the property in trust to the Trustee and make the latter the agent of the Settlor, the Beneficiary, or both. Yet "If [an agent] has title, either legal or equitable, to property which he holds subject to equitable duties to deal with it for the benefit of another, he is a trustee." Restatement (Second) of Agency, $\S 14 \mathrm{~B}$, Comment $b$. Thus, to eliminate the law of trusts would seem to eliminate (by definition) the possibility of an agent who holds only legal title while the "equitable" interest lies elsewhere. While it is perfectly conceivable - and common - for a legal regime to adopt the law of trusts without adopting the law of equity in general, it is harder to know what it would mean to have the law of equity without the law of trusts.

32. Restatement (Second) of Trusts $\S \S 261,262$. 
signing a contract that she is signing strictly as trustee for the trust and not in her personal capacity. ${ }^{33}$ Moreover, and noncontractual liability imposed on the trustee as title holder is limited to the extent she can obtain indemnity from the trust. ${ }^{34}$

This seems the sensible approach. In most cases, so long as the third party creditors are aware that they are dealing with property in trust, it is probably inefficient to make the trustee personally liable for obligations entered into for the benefit of the Beneficiary in the course of administering the property in trust. The reduced cost of credit for the trust resulting from such a rule would, in general, be more than offset by the increase in the cost of credit for the Trustee in her personal (and other business) transactions owing to the increased complexity in monitoring credit that the rule would impose on all of the creditors involved. Moreover, the incentive effects of such a rule for the Trustee also appear unattractive, since the rule would tend to induce severe conservatism by giving the Trustee a personal stake in the losses, but not the gains, resulting from her administration of the property in trust. Thus, the efficient rule would seem to be no personal liability to third parties for a non-negligent Trustee acting within the scope of her authority.

If limited liability for the Trustee were the unconditional default rule, however, there would arise the possibility that creditors might be misled into believing that they are dealing with the Trustee in her personal capacity rather than just in her capacity as Trustee, and would consequently extend credit on more generous terms than they would have if they had realized that they could not rely upon the Trustee's personal assets for security. By requiring that the Trustee give creditors clear notice before she can avoid personal liability, the prevailing trust rule assures both limited liability for the Trustee and clear signalling to creditors of the assets on which they can rely. And, here as elsewhere, the existence of the trust as a standard form makes it easy for the Trustee to send this signal because, in signing a contract, she need simply use the phrase "as trustee for $\mathrm{X}$ and not individually" to convey to creditors what the situation is. ${ }^{35}$ Absent trust law, the Trustee would need to insert explicit language in each of her contracts insulating her personal assets from creditors' claims - a costly burden that would presumably be impractical in many circumstances.

In short, trust law establishes here a "penalty default" - that is, a default rule of liability for the Trustee that is generally inefficient, but that gives the Trustee an incentive to reverse the rule by revealing clearly to third parties that she is, in fact, just a Trustee, and

33. Restatement (Second) of Trusts §263.

34. Id. \$265.

35. Id., comment a. 
that the third parties may turn only to designated property in trust for their security. ${ }^{36}$

\section{9. " Liability of the Settlor}

Under trust law, the settlor as such is not personally subject to liabilities incurred in the administration of the trust. ${ }^{37}$ Where the Settlor is not also a Beneficiary, this rule is easy to understand. The Settlor typically has little or no control over the ongoing administration of the property in trust; indeed, the default rule in trust law is that the settlor has no right to enforce the trustee's duties. ${ }^{38}$ Further, total monitoring costs for the creditors of the property in trust and the personal creditors of the Settlor will likely be minimized if the former creditors need only monitor the property in trust and not the personal finances of the Settlor, while the latter creditors need only do the reverse. Finally, by requiring that a Trustee indicate that she is acting "as trustee," the law of trusts effectively assures that creditors are on notice that the Settlor's personal assets not are pledged as security for liabilities incurred by the Trustee. (We postpone to the following section the case in which the Settlor is also a Beneficiary.)

In the absence of trust law, and with only contract, agency; and property law to work with, creation of a trust-like relationship in which the Settlor is free of personal liability would be difficult. In particular, if (as seems the natural alternative) the Trustee were made the agent of the Settlor, contracts entered into by the Trustee would generally be presumed to bind the Settlor as principal. The latter result could be avoided by putting a specific waiver of the Settlor's liability into all contracts entered into by the Trustee in connection with the property in trust, but for the reasons noted earlier this individual contracting approach would likely be both unreliable for the Settlor and costly or impractical for the Trustee.

\section{Liability of the Beneficiary}

Trust law also provides that the beneficiary is not personally subject to contractual commitments and other liabilities incurred in the administration of the trust. ${ }^{39}$ In the absence of trust law, this result might be difficult to obtain even where the Beneficiary is not

36. On penalty defaults in general, see Ayres \& Gertner, "Filling Gaps in Incomplete Contracts: An Economic Theory of Default Rules," 99 Yale L. J. 87 (1989); Schwartz, supra n. 33.

37. Pottorff v. Dean, 77 F.2d 893 (8th Cir. 1933). The principal exception is the case in which the settlor - particularly in the role of combined settlor/beneficiary retains sufficient control over the conduct of the trustee as to make the trustee the settlor's agent. See the discussion of beneficiary liability immediately below.

38. Restatement (Second) of Trusts, $\$ 200$, Comment b.

39. Restatement (Second) of Trusts \$\$274-77. 
the Settlor: an effort to establish a trust-like relationship could well lead to the Trustee being characterized under the law as the Beneficiary's agent, with the consequence that contracts entered into by the Trustee for the Beneficiary's benefit would bind the Beneficiary as well, whether or not the third parties knew that the Trustee was acting for the Beneficiary. ${ }^{40}$ Indeed, absent the law of trusts, it would be difficult to establish a trust-like relationship without the Trustee being characterized as the agent of either the Settlor, the Beneficiary, or both, with the result that at least one of these two parties would be personally liable for obligations of the trust. (Thus, where the Beneficiary is also the Settlor, characterization of the Trustee as the agent of the Settlor/Beneficiary, and consequent personal liability for the latter, would seem unavoidable.) Further, as just noted in connection with personal liability for the Settlor absent trust law, efforts to avoid personal liability by contractual waivers from individual creditors would be a very inferior substitute for trust law. Indeed, the risk that a careless or unfaithful Trustee would fail to insist on waivers would presumably be highest precisely where unlimited liability for the Beneficiary is least appropriate, namely where the Beneficiary lacks not only the competence to manage the property in trust by himself, but also the ability to monitor the Trustee.

At least so far as voluntary creditors are concerned, trust law's reversal of the agency law rule seems efficient. First, although the beneficiary receives the benefit - the residual returns - from the trust property, in common uses of the trust he typically exercises little direct control over it. Consequently, the beneficial incentive effects of personal liability for the Beneficiary would generally be modest at best. ${ }^{41}$

Second, and perhaps more importantly, since title to the trust property is in the Trustee's rather than the Beneficiary's name, persons who are contemplating extending credit to the trust are unlikely to be misled into believing that they will be able to rely on the Beneficiary's personal assets for satisfaction of their claims, and can make appropriate adjustments in the terms on which they extend credit. The ability of creditors to make those adjustments is enhanced, moreover, by the fact that private trusts are most commonly employed where the property in trust consists of a discrete pool of assets that are segregated from other assets owned by the Beneficiary and whose management is unrelated to that of the Beneficiary's other assets,

40. Restatement (Second) of Agency $\$ \S 140,144,186$.

41. Moreover, in the traditional three-party trust (as opposed to two-party trusts in which an individual simply delegates management of property to a an expert for the individual's own benefit), the original decisions to create the trust, to contribute assets to it, and to select the Trustee are all made, not by the Beneficiary, but by the Settlor, so that personal liability for the Beneficiary would also have no useful incentives with respect to creation of the trust. 
and by the fact that the Trustee (if she wishes to avoid personal liability herself) will signal to third parties that they are dealing with a trust, which will put those third parties on clear notice that the liability of the Beneficiary is limited to the trust assets.

Third, as with limited liability for the Settlor, limited liability for the Beneficiary (or the Beneficiary/Settlor) is likely to minimize the total costs of monitoring for the creditors of the Property in trust and the Beneficiary combined, and hence minimize the total costs of credit. Or at least this seems true for the purposes for which trusts are commonly used, such as asset management. Where it is not true, it is open to the Settlor/Beneficiary to assume personal liability for trust debts explicitly or to adopt a different organizational form, such as a partnership with the Trustee, which automatically brings personal liability and hence pledges his personal assets as security for transactions with the Property in trust.

\section{Relationship with Third Parties Acquiring the Property in Trust}

Another class of third parties whose contractual relationships are affected by trust law are persons to whom the Trustee sells or donates Property in trust. Under the law of trusts, if the trustee transfers trust property to someone in breach of the terms of the trust, the beneficiary can recover the property and any income derived from it if the transferee is anyone other than a good faith purchaser who gives something of value in exchange for the property (i.e., is not a donee) and has no notice of the trust. The beneficiary's claims, moreover, are supported by an equitable lein on the property and its proceeds. ${ }^{42}$ It is easy to rationalize, on efficiency grounds, a rule at least this protective of the Beneficiary: in the circumstances in which the rule operates, the third-party transferee is almost by definition a lower-cost monitor of the Trustee's breach of duty than is the Beneficiary.

If the default rule were different - if, for example, a purchaser from the trustee always took good title - then it would be virtually impossible for the Settlor, the Trustee, and the Beneficiary to establish by contractual means the regime that is now the trust law default rule. This rule, then, is a significant contribution that the law makes to the creation of trust-like relationships. The extent to which it is a contribution of trust law, however, is subject to debate. The remedies that the common law of agency gives to principals when their agents make unauthorized transfers of property are of similar character. ${ }^{43}$ Perhaps more important than the default rule remedies,

42. Restatement (Second) of Trusts \$§287-295.

43. One cannot say precisely what rules agency law would provide in the absence of trust law, since agency law explicitly incorporates the trust law rules when an agent holds title for the benefit of the principal. Restatement (Second) of Agency 
moreover, is the way in which trust law facilitates signaling to third parties the existence of the trust-like relationship, and hence helps put them on notice that the Trustee lacks authority to make the transfer.

\section{Conclusion: The Important Contribution of Trust Law}

In sum, it appears that the important contribution of trust law lies not in its ordering, via default rules of contract, of the relationships among the three principal parties to a trust-like relationship the Settlor, the Trustee, and the Beneficiary - but rather in its ordering of the relationships between those persons and third parties with whom they deal. It is the latter relationships that, owing to high transaction costs, cannot be easily rearranged by contractual means.

The most significant of the contractual default rules that trust law establishes with respect to third parties are those governing creditors' rights. Those rules provide a convenient means by which the three principal parties can partition off a discrete set of assets - the property in trust - not only for separate delegated management, but also for purposes of pledging those assets, taken together, to a distinct group of creditors as security.

The modern commercial uses of the trust form, which are now by far the dominant uses, illustrate quite clearly the crucial role that creditors' rights play in trust law.

Consider, first, the pension fund. In the United States, the typical pension fund is a pool of assets that is accumulated as a reserve with which to pay the pensions of the employees at a given firm, and that is both funded and managed by the corporation whose employees are covered by the fund.

The Employee Retirement Income Security Act of 1974 (ERISA) requires that pension fund assets be held in trust form. ${ }^{44} \mathrm{~A}$ critically important consequence of this requirement - and presumably the principal motivation for it - is to assure that the fund's assets will be immune from claims of the corporation's creditors. If it were otherwise - if, for example, a pension fund were just an investment account maintained by the corporation within its corporate shell then the employees' pensions would always be subject to the risk of the corporation's insolvency. Thus, bankruptcy of the corporaton could deprive the employees not only of their jobs but of their retire-

$\S 202 \mathrm{~A}$. But compare id. $\$ \S 200-01$, concerning the extent to which a principal is bound when an agent makes an unauthorized transfer of a chattel whose possession has been entrusted to her.

44. Employee Retirement Income Security Act of 1974 §403, 29 U.S.C. \$1103. There are limited exceptions, including principally assets of a pension plan that consist of insurance contracts or policies. Id. 
ment savings as well. Worse, if pension assets were available to the corporation's creditors, corporate shareholders and trustees would have both the incentive and the ability to have the corporation take on inefficiently risky investments, knowing that if the investments succeed the shareholders will get the gains, while losses will be borne in substantial part by the employees.

ERISA's insistence on use of the trust form does not, in contrast, serve as a means of imposing on the trustees of pension funds the standard form fiduciary duties that trust law imposes on trustees. Instead, ERISA spells out those fiduciary duties on its own, and thus imposes them directly without relying on trust law. ${ }^{45}$ One reason for this is to impose on the trustees of pension funds some detailed obligations appropriate to such funds. ${ }^{46}$ Another, presumably, is to limit the flexibility that trust law might otherwise afford to deviate from important elements of the standard form duties.

Immunity from the creditors of the fund's trustee is also a critical reason for use of the trust form for mutual funds. If a fund's trustee were simply the agent of the fund's investors, then the fund's portfolio would always be at risk of the fund trustee's insolvency - a risk that the investors would have great difficulty monitoring or controlling. For this reason, mutual funds that are not formed as trusts are typically formed as business corporations, which achieves the same immunity of the fund's portfolio from the involvency of the trustees.

As with pension funds, the trust form is clearly not being used for mutual funds to take advantage of the particular fiduciary duties that are the default rule in trust law. The fact that nearly half of all mutual funds are formed as corporations, which have somewhat less rigorous standard form fiduciary duties (roughly those of agency law), is one indication of this. Another is that the Investment Company Act of 1940, which governs mutual funds, imposes its own fiduciary duties on the trustees of investment companies. ${ }^{47}$

Another example: in a typical asset securitization transaction, a business corporation forms a private trust and transfers to that trust title to some subset of the corporation's assets - say, its accounts receivable - that yield an income stream. The trust in turn issues bonds that are backed by those assets, and pays the proceeds of the bond sale to the corporation. Thus, the trust is used as an intermedi-

45. Employee Retirement Income Security Act of $1974 \S \S 404-12$, 29 U.S.C. $\S \$ 1104-12$.

46. See George G. Bogert \& George T. Bogert, The Law of Trusts and Trustees $\S 255$ ( 2 d ed. 1992).

47. Investment Company Act of $1940 \S 17,15$ U.S.C. $\$ 80 a-17$, sets out rules on conflicts of interest and establishes minimum standards of care for the directors or trustees of investment companies. Nearly all the terms of the Act, however, are designed to protect the investors who are the beneficial owners of the assets of investment companies. 
ary in a transaction in which a corporation pledges some of its assets as security to back an issue of marketable bonds.

Why use the trust, rather than just have the corporation issue the bonds itself, pledging its accounts receivable as security? The answer is that the trust permits a very clear partitioning of the corporation's assets into different subsets that can be separately pledged as security to different groups of creditors. The result is to reduce the total costs of monitoring for the corporation's creditors, and hence reduce the corporation's cost of credit. ${ }^{48}$ For this purpose, an essential feature of the trust is that it is (in the language of the securitization literature) "bankruptcy remote" - that is, it will be unaffected by the bankruptcy of the corporation, and in particular will maintain secure title to the assets it holds (the corporation's accounts receivable, in our example) even if the corporation goes into bankruptcy. ${ }^{49}$ Thus, the accounts receivable can be pledged more effectively as security for the bonds than would be the case if the corporation were to issue the bonds itself. By this means, corporations that, taken as a whole, present a relatively high level of risk to their creditors are able to secure financing through the issuance of high-grade bonds. ${ }^{50}$ Once again, it is the immunity of the Property in trust (the accounts receivable) from the bankruptcy of the Settlor (the corporation) and the Trustee (which would be the corporation in the absence of the trust) that is the crucial contribution of the trust form to this transaction. The particular fiduciary duties imposed by trust law, on the other hand, are of little importance, since they are largely displaced by the highly detailed provisions of the trust agreement. ${ }^{51}$

Private trusts serve a variety of useful transactional purposes. The most important contribution of trust law to the accomplishment of these purposes is that it facilitates a particular partitioning of assets for purposes of pledging those assets to creditors. Unlike other aspects of the trust as an institution - including, in particular, the fiduciary duties that trust law imposes - this asset partitioning would be difficult or impossible to arrange if the law of trusts did not exist.

48. See Hill, "Securitization: A Low-Cost Sweetener for Lemons," 74 Wash. U. L. Q. 1061, 1090-93 (1996).

49. See Schwarcz, "The Alchemy of Asset Securitization," 1 Stan. J. L. Bus., \& Fin. 133, 135 (1994).

50. Hill, supra n. 48 , at 1073.

51. Id. at 1126, n. 163 . 
